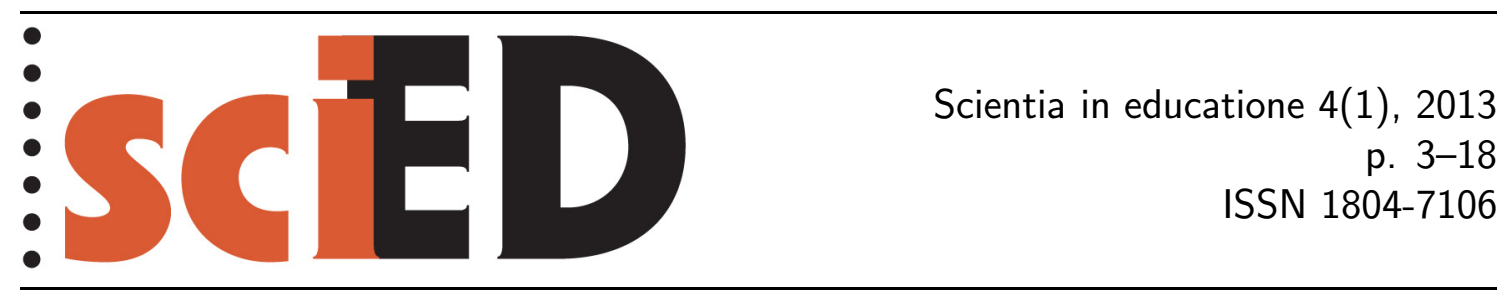

\title{
Experimentálna podpora vo vyučovaní fyziky na základných školách
}

\author{
L’uboš Krišták, Ján Stebila, Zuzana Danihelová
}

\begin{abstract}
Abstrakt
V príspevku poukazujeme na možnosti použitia moderných interaktívnych metód pomocou doplnkovej učebnej pomôcky vo forme multimediálneho DVD vo vyučovaní tematického celku venovaného jadrovej fyzike na základných školách na Slovensku. Tažiskom príspevku je pedagogický výskum, ktorého cielom bolo prakticky overit efektívnost použitia multimediálneho DVD z jadrovej fyziky v reálnych podmienkach základnej školy. Predpokladáme, na základe pilotného prieskumu, že multimediálne DVD zvýši efektívnost vyučovania tematického celku venovaného jadrovej fyzike v predmete Fyzika v 9. ročníku ZS̆.
\end{abstract}

Klíčová slova: vyučovanie fyziky, jadrová fyzika, základná škola, multimediálne DVD, PC.

\section{Experimental Support in Teaching Physics at Lower Secondary Schools}

\begin{abstract}
The paper mentions the possibilities of using modern interactive methods with supplementary teaching aid in a form of multimedia DVD in teaching the topic - nuclear physics at lower secondary schools in Slovakia. The main part of the paper is a pedagogical research aimed at practical verification of the use effectiveness of multimedia DVD from nuclear physics in real lower secondary school conditions. It is supposed, following a basic pilot research, that the multimedia DVD increases the effectiveness of the teaching process concerning the topic of nuclear physics in the subject Physics in the $9^{\text {th }}$ grade of lower secondary school.
\end{abstract}

Key words: teaching Physics, nuclear physics, lower secondary school, multimedia, PC. 


\section{INTRODUCTION}

Key competences of pupils and their development have become more current recently in Slovakia. This fact is a consequence of the Slovak pupils results in international researches; e.g. the studies of the Organisation for Economic Co-operation and Development (OECD) and PISA (Programme for International Student Assessment) carried out in 2006 aimed at the scientific literacy showed that the Slovak pupils, in comparison to other OECD countries, achieved significantly lower statistical results than the average of OECD countries. The research showed that Slovak pupils can describe scientific issues; they are able to select the knowledge and facts appropriately in order to explain the issues and are able to use simple models; but they have problems with hypotheses stating, with experimenting as a tool for data acquisition and their subsequent analysis, interpretation and conclusion formulation (Krupová, 2009; Hockicko, 2010; Dvořák et al., 2008).

In the 1980's David Hestenes and Ibrahim Halloun (Halloun, Hestenes, 1985) from the USA published papers on didactic research, whose object were students of secondary schools and universities, dealing with misconceptions in Newtonian dynamics. One of the research results was a test Force Concept Inventory (FCI) (Hestenes et al., 1992) containing questions from Newtonian mechanics connected to everyday life. The authors decided to research whether the students understand the basic concepts from mechanics sufficiently; how they are able to work with them and apply them into various everyday situations (Slovak version Hanč and Tóth, 2006). The test results from the whole world showed that the traditional teaching of the Newtonian mechanics at secondary schools eliminates wrong students' perception, acquired during their lower secondary school studies, only to a small extent. Following, conceptual tests from further areas of Physics (dynamics, wave, heat and temperature, electricity and magnetism, quantum mechanics, nuclear physics, etc.) confirming this theory were created. It was also shown that traditional classes having a form of presentation or traditional quantitative physical tasks, even with the best and most talented teachers, help also excellent students to acquire only basic knowledge without deeper understanding and to algorithm solving of problems; the students do not show conceptual understanding of the subject which should result from a sufficient number of solved quantitative tasks and from logically clear lectures (Hake, 1998; Hanč et al., 2007; Redish, 2003). Next important conclusion of using these tests was that the misconceptions (in all areas of Physics) and their accumulation in further study cause that students do not understand the subject dealt with and they are learning the subject by heart what consequently leads to frustration (Martin-Blas et al., 2010).

Research results of D. Hestenes, I Halloun and others (Arons, 1985, 1997; McDermott, 2001; Nachtigall, 1990) have led to a significant change in the view of the teaching Physics. Many teachers of Physics at lower secondary schools, secondary schools and universities think that teaching Physics does not have the nature of science and is mainly about so called pedagogical talent of the teacher. However, the research results of these (and also other) groups have shown that teaching Physics can be scientific based and methodology of Physics can be understood as a systematic scientific discipline whose procedures and results can be reapplied. A pupil can understand scientific concepts and theories truly only through steady deductive and inductive mental activities and reasoned interpretation of their own understanding of reality. Pupils who are only listening passively during the teaching process show only seldom such activities (Demkanin et al., 2011). Therefore, one of the most 
important assumptions for changing the teaching Physics is the change of the position of pupil to an independently and actively learning element of the teaching and learning process (Redish, Steinberg, 1999).

This knowledge has recently become a base for the rise of new approaches and methods used in the teaching Physics; their use brings about significantly better results than the use of traditional methods. Some of these methods are PI (Peer Instruction), ILD (Interactive Lecture Demonstration), JiTT method (Just in Time Teaching), Interactive Examples, Mastering Physics, Interactive ComputerBased Tutorials etc. (Crouch, Mazur, 2001; Mazur, 1997; Sokoloff, Thorton, 1997; Zacharia, Anderson, 2003). These methods emerge mainly from the interaction between the lecturer and students, whereas students are actively involved into individual stages of the teaching and learning process and actively participate in solving of the dealt problems what gives an immediate feedback to the lecturer and he/she can immediately respond to incorrectly understood concepts, or misconceptions.

Another approach used in the teaching Physics that has become popular in the recent years is multimedia technologies. Multimedia technologies showed their potential in teaching such subjects. New techniques increase pupil's attention - it enables easier and faster learning. Pupils like to work with computers and modern information technologies. If we connect working with computer with the study of Physics such form will be very interesting for pupils and it can be supposed that they will achieve better study results (Sturm, 2009). It can be supposed that multimedia support can increase the effectiveness of technical education at lower secondary schools (Shelly et al., 2001; Žáčok, 2010).

\section{Nuclear Physics at Lower Secondary SCHOOLS}

The paper is focused on the area of nuclear physics presented in the $9^{\text {th }}$ grade of lower secondary schools in the Slovak Republic (within the topic "Energy in Nature, Technology and Society" within 20 lessons). Consultations with lower secondary school teachers (in Slovakia) revealed that they deal with the topic of nuclear physics within $4-5$ lessons on average; within these lessons they deal with following topics:

- Nuclear energy and its utilisation

- Nuclides, natural and artificial radionuclides

- Fission of uranium nuclei, nuclear chain reaction, nuclear power plant

- Radionuclides in practice

- Principles of protection against nuclear radiation

In spite of the difficulty and excessive abstractness of this area of Physics Slovak course books do not contain any experiments enabling better understanding of such a difficult issue (Krišták, 2007). Experiments from the nuclear physics are not mentioned either in the curriculum for the lower secondary schools. This results in a situation when the schools in the Slovak Republic do not have any equipment for carrying out experiments, any methodical materials and as a consequence such experiments are not carried out at all. In contrast schools in the Czech Republic are equipped with the set Gamabeta (provided by the České energetické závody) which contains a radioactive emitter, Geiger - Müller counter, adsorbents from various materials and in various thicknesses and a sample of a fire alarm. This set provides a 
possibility of demonstrating radiation indication, influence of the distance, shielding, etc.

One of the possibilities of reducing the excessive abstractness and difficulty of the given chapter is the integration of experiments into the chapter and their combination with interactive teaching methods. Nuclear physics experiments are a suitable tool for the development of scientific literacy of the $9^{\text {th }}$ grade pupils; according to mentioned study of PISA, scientific literacy belongs to the key competences. The use of interactive methods and experiments can increase demonstration of physical phenomena being dealt with in a class. Moreover, experiment can increase pupils' interest in Physics, motivate them to an increased activity and contribute to the development of creative skills. The use of experiments prepares the pupils for solving tasks which they can later encounter in everyday life (Zelenický, 1991). Creative experiments integrated into the teaching process increase the level of understanding and attention of pupils and at the same time the theory of Physics is becoming interconnected with everyday life (Nachtigall, 1990; Bussei and Merlino, 2003; Dykstra et al., 1992).

Following a comparison in the teaching of nuclear physics in Slovakia and other countries, we realised that while in the Slovak Republic this area of Physics is being dealt with purely theoretically in other countries many demonstration and pupil experiments are being carried out. We compared the ways of teaching of nuclear physics at lower secondary schools in Slovakia and some countries of the European Union and the United States of America; we obtained an analysis (Krišták, 2008) which was a base for the creation of multimedia materials from nuclear physics for lower secondary schools in Slovakia.

Within the analysis the focus was on:

1. classification of nuclear physics in the system of Physics at lower secondary school

2. contents of the curriculum of nuclear physics

3. carrying out demonstration and pupil measurements during classes

4. carrying out practical laboratory measurements

This analysis was elaborated following the curricular documents valid in individual countries, used course books, various supplementary materials in individual countries and questionnaires and interviews with the teachers.

While Slovak lower secondary schools have not experienced such experiments by now, in other countries they are a common part of the teaching process (Tab. 1).

Table 1: Comparison of using experiments in teaching of nuclear physics at primary schools in Slovakia and other countries

\begin{tabular}{|c|c|c|c|c|c|c|}
\hline & Slovakia & England & Austria & Germany & Poland & USA \\
\hline $\begin{array}{c}\text { Number of } \\
\text { experiments } \\
\text { carried out* }\end{array}$ & 0 & 4 & 5 & 5 & 2 & 6 \\
\hline $\begin{array}{c}\text { Way of } \\
\text { carrying out } \\
\text { experiments }\end{array}$ & pupil & $\begin{array}{c}\text { pupil } \\
\text { experiments, } \\
\text { simulations }\end{array}$ & $\begin{array}{c}\text { puppil } \\
\text { demonstration } \\
\text { experiments }\end{array}$ & $\begin{array}{c}\text { experiments, } \\
\text { demonstration } \\
\text { experiments }\end{array}$ & simulations & simulations \\
\hline
\end{tabular}

*average number resulting from the questionnaire answers sent to the teachers in individual countries (considered were only countries, from which a minimum of 100 questionnaires returned). The table illustrates numbers of experiments carried out really by the teachers. 


\section{Multimedia DVD From Nuclear Physics}

We created a multimedia DVD from nuclear physics. The aim, during its creation, was the implementation of interactive methods with elements of a real laboratory into the teaching of scientific and technical subjects. During the creation of the DVD we tried to use the positive sides of experiments, problem task solving and interactive methods in teaching Physics (mainly Peer Instruction, Interactive Lecture Demonstrations, Just in Time Teaching and Interactive Computer-Based Tutorials).

The attention was paid to the area of nuclear physics at lower secondary schools as this topic in Slovakia does not contain any experiments and it is dealt only in theory.

The contents of the multimedia DVD is divided into three main parts:

1. The first part is theoretical, i.e. elaborated curriculum from nuclear physics. Created text goes out from the original text from the course book "Fyzika

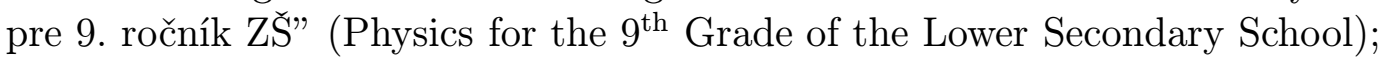
the text has been changed only minimally for the needs of experiments integration into the teaching of this topic. As today's curriculum in course books of scientific subjects is being said to be excessive, we tried not to introduce new concepts. Introduction of new concepts was only due to experiments integration; we suppose that the level of difficulty of experiments is appropriate for the $9^{\text {th }}$ grade of lower secondary school. Mentioned changes were carried out only in chapters that enabled integration of practical experiments. Other chapters remained unchanged.

2. The second part deals with experiments. The analysis of foreign course books was the base for creating the experiments form nuclear physics. It was necessary to create an accompanying text to the experiments for teachers and pupils to enable them as effective carrying out of experiments as possible. Therefore, this part is divided into three parts: guidelines for teachers, worksheets for pupils and videos. Individual stages of experiments were selected in order to develop, beside practical skills, also creativity. This part includes 9 experiments altogether: measuring of atmospheric radioactivity, absorption of beta radiation, range of alpha particles in the air, statistics of radioactive decay, half life of radioactive emitter, measuring by means of a ionisation chamber, absorption of radioactivity by means of different materials and gamma ray absorption measurements.

3. The third part of the multimedia DVD consists of problem tasks from nuclear physics elaborated in the style of PISA tasks; their aim is to verify pupils' understanding of the topic, or the teacher can use them as an input problem.

Mentioned structure of the DVD was testes and verified in the teaching process at secondary schools and universities using the interactive method based on an increased focus on problem tasks and experiments P\&E (Krišták, Němec, 2011). This method has four phases and can be used in nuclear physics teaching at lower secondary schools:

1. Preparatory phase: In the case of lesson aimed at explanation the teacher sets the basic concepts which he/she wants to explain and deal with in the lesson. He/she prepares a block of 5-10 minutes for each concept. Within this block the concept is being dealt with and the teacher also prepares few physical problems connected to the given concept. 
2. Dealing with the concept: The teacher teaches the 5-10 minute block during which he/she deals with the important physical concept (or more concepts).

3. Assignment of a problem: Presentation of a problem task connected to the dealt concept follows. Problem task can be, in the case of P\&E method, assigned in for ways:

- task assigned in the form of a text,

- via experiment - teacher performs a simple experiment. To explain this experiment it is necessary to understand the concept dealt with during the previous block (it can be a traditional or computer aided experiment),

- via video-experiment - teacher plays experiment recorded by a video camera (Brown, Cox, 2009; Hockicko, 2011),

- via applet (simulation) (Campbell et al., 2002; Finkelstein et al., 2005)

For each way of setting of problem pupils' worksheets and teachers' guidelines were created. Pupils get a worksheet for each problem dealt with in a lesson (assigned in any way).

4. Problem solving: After the teacher assigned the problem (in one of the four ways) a class discussion follows. Within the discussion the pupils, under the teacher's supervision, discuss possible solutions of the given problem. Teacher gradually writes the solutions on the board. Discussion about individual solutions follows; incorrect solutions are excluded following a physical reasoning. This process continues until there is only one correct solution. Pupils write into their worksheets incorrect solutions including the physical reasoning and also the correct solution including the physical reasoning. In the next part the teacher explains the connection of the given problem to everyday life and practice and where the pupils can encounter this, or similar problems. At the end of this part the teachers goes with the pupils through the questions and tasks assigned in the pupils' worksheets.

Examples of pupils' worksheets for problems assigned in a form of a real computer aided experiment:

\section{Pupils' worksheet for a real computer aided experiment}

Pupils' worksheets contain all information necessary for carrying out experiment (Raganová et al., 2007).

Structure of pupils' worksheets:

Name of the experiment

A little bit of theory - the introduction can contain an example from everyday life that motivates pupils to solve the problem raised at the end of this part.

What do we need - list of aids used during the experiment.

Scheme of the experiment - detailed scheme of the experiment development.

How will we proceed - detailed procedure of the experiment.

Processing of measured data - procedure how to analyse measured data.

Think - questions connected to measured values and processed results. Following the questions pupils analyse achieved results deeper. 
Connection to life and practice - in this part pupils learn what practical impact of the given experiment is and where, in everyday life, they can come across it or similar experiments.

Proposals for further activities - this part is comprised of ideas for further activities closely connected to the carried out experiment.

Questions and tasks - additional questions and tasks corresponding to the experiment and phenomena closely connected to it.

\section{Teachers' guidelines for real computer aided experiments}

Guidelines are aimed for teachers and contain all information necessary for carrying out experiments. They include also information when to carry out the given experiment or other information needed for pupils' safety (Holec et al., 2004).

Structure of teachers' guidelines:

Name of the experiment

Integration of the experiment into topic - topics which the given experiment corresponds to and into which it can be included.

Objective of the experiment — what we want to achieve with the experiment, its brief description.

Notes to carrying out of experiment - additional information to the experiment.

Processing of measured data - the way how to process measured data and draw a conclusion.

Experiment conclusion - what was achieved by the experiment; what conclusions result from the experiment; solving of additional questions.

Pupil activities - proposals for further activities for pupils connected to the experiment.

Providing that schools do not have sufficient material and technological equipment it is possible to make a video-experiment including complete video-analysis. When doing video-experiment teacher's activity is very important; teacher can comment on the experiment during its process or stop some passages eventually repeat them several times. From this reason teacher's guidelines contain also time schedule of the video.

\section{Pedagogical Experiment}

\section{ReseARCH OBJECTIVES}

The main objective was to verify the effectiveness of using the multimedia DVD from nuclear physics in real conditions of selected lower secondary schools in the subject Physics.

To reach the aim partial tasks were determined:

- to verify stated hypotheses using research tools and methods;

\section{RESEARCH HypothesES}

Based on the aforementioned objective the main hypothesis was formulated:

$\mathrm{H}$ : The use of multimedia DVD from nuclear physics in the teaching Physics in the 
$9^{\text {th }}$ grade of lower secondary school influences the level of pupils' knowledge from nuclear physics from the point of view of statistical significance.

To verify the main hypothesis operational hypotheses were stated:

$\mathrm{H}_{1}$ : At the end of the experimental teaching process pupils taught by the multimedia DVD achieve higher performance in didactic test in the area of specific and nonspecific transfer than pupils taught traditionally.

$\mathrm{H}_{2}$ : At the end of the experimental teaching process pupils taught by the multimedia DVD achieve higher performance in didactic test in the area of remembering than pupils taught traditionally.

$\mathrm{H}_{3}$ : At the end of the experimental teaching process pupils taught by the multimedia DVD achieve higher performance in didactic test in the area of understanding than pupils taught traditionally.

\section{SELECTION OF RESPONDENTS}

4 experimental and 4 control groups were selected from four lower secondary schools (Tab. 2). Within individual schools the groups were selected according to the level of knowledge from Physics characterised by the mark from Physics at the end of the $8^{\text {th }}$ grade and the terminal mark in the $9^{\text {th }}$ grade.

Table 2: Structure of individual control and experimental groups

\begin{tabular}{|c|c|c|}
\hline School Name & Experimental group & Control group \\
\hline I & 43 & 43 \\
\hline II & 28 & 26 \\
\hline III & 22 & 22 \\
\hline IV & 21 & 20 \\
\hline TOGETHER & 104 & 101 \\
\hline
\end{tabular}

The research was carried out on 205 pupils; 104 were in 4 experimental groups and 101 were in 4 control groups.

\section{Research Methods And Techniques}

To achieve the stated objectives and to verify hypotheses following research methods and techniques of empirical research were proposed:

- pedagogical experiment

- didactic test (DT) for verifying operational hypotheses $\mathrm{H}_{1}-\mathrm{H}_{3}$

- statistical methods for research results processing.

After the selection of suitable groups the pedagogical experiment followed simultaneously during one year in all groups. The same teacher taught in experimental and control groups at each school. In control groups the teaching process was carried out in a traditional way, i.e. without the use of experiments; neither any interactive methods nor problem tasks were used (multimedia DVD was not used).

In experimental groups almost the same curriculum as in control groups (extended minimally for the needs of experiments) was dealt with and experiments were carried out. Each experiment was used to introduce a problem task whereas the 
pupils were provided with pupils' worksheets and teachers with teachers' guidelines for each problem task (P\&E method). 5 experiments were carried out altogether; some were demonstration some pupil experiments. While doing demonstration experiments one measuring set was used; experiment was demonstrated by the teacher with the help of pupils. During pupil experiments three measuring sets were used whereby pupils were divided into three groups.

When dealing with the topic of nuclear physics pupils did not know that they were a part of a pedagogical experiment. After the experiment pupils in all groups took a didactic test. In the didactic test pupils' knowledge on the three levels of educational objectives (remembering, understanding, specific and non-specific transfer - the use of information in typical and problem situations - Tab. 3) was studied.

Table 3: Educational objectives

\begin{tabular}{|l|l|}
\hline Educational objective & Pupil is able \\
\hline Remembering the information & $\begin{array}{l}\text { To recall, recognise and reproduce } \\
\text { concepts, facts, relationships, etc. }\end{array}$ \\
\hline Understanding the information & $\begin{array}{l}\text { To transform remembered information } \\
\text { (knowledge) and put them forward in } \\
\text { a summarised way, in a correct order, } \\
\text { explain them in own words, explain } \\
\text { the meaning, etc. }\end{array}$ \\
\hline $\begin{array}{l}\text { The use of information in typical and } \\
\text { problem situations (specific and } \\
\text { non-specific transfer) }\end{array}$ & $\begin{array}{l}\text { To apply the knowledge, solve } \\
\text { analogical tasks, formulate problems, } \\
\text { perform analysis, synthesis, solve } \\
\text { problem tasks, etc. }\end{array}$ \\
\hline
\end{tabular}

All pupils had the same didactic test containing 17 questions (Appendix). Questions were selected after an agreement with teachers. The majority of questions were open, some were multiple choice. Pupils had 35 minutes to do the test and could reach a maximum of 30 points. The correct answer was evaluated with 1-3 points, according to the level of difficulty (Tab. 4). After the pedagogical experiment the obtained data was collected and statistically and qualitatively analysed.

Table 4: Four levels of learning in the used test

\begin{tabular}{|c|c|c|c|}
\hline & Remembering & Understanding & $\begin{array}{c}\text { Specific and } \\
\text { nonspecific } \\
\text { transfer }\end{array}$ \\
\hline Points & 1 & 2 & 3 \\
\hline Question in test & $2,7,8,9,11,12,15,16,17$ & $3 \mathrm{a}, 3 \mathrm{~b}, 5,6,14,10$ & $1,4,13$ \\
\hline
\end{tabular}

\section{RESEARCH RESUlts}

To verify hypotheses $\mathrm{H}_{1}-\mathrm{H}_{3}$ a non-standardised didactic test - posttest, taken by pupils after dealing with the topic devoted to nuclear physics, was used (see appendix). Within the evaluation of the hypothesis $\mathrm{H}_{1}$ only tasks aimed at specific and non-specific transfer were evaluated; within hypothesis $\mathrm{H}_{2}$ only tasks aimed at remembering and within hypothesis $\mathrm{H}_{3}$ tasks aimed at understanding (Tab. 4). 
Table 5: F-Test: Two-Sample for Variances, t-Test: Two-Sample with Equal Variances (Hypothesis $\mathrm{H}_{1}$ )

\begin{tabular}{|c|c|c|}
\hline & Experimental & Control \\
\hline Mean & 68.40 & 53.50 \\
\hline Variance & 150.96 & 211.65 \\
\hline Observations & 104 & 101 \\
\hline $\mathrm{d} f$ & 103 & 100 \\
\hline$F$ & \multicolumn{2}{|c|}{0.71} \\
\hline$F$ Critical one-tail & \multicolumn{2}{|c|}{0.72} \\
\hline Pooled Variance & \multicolumn{2}{|c|}{203} \\
\hline $\mathrm{d} f$ & \multicolumn{2}{|c|}{7.94} \\
\hline$t$ Stat & $6.95 \cdot 10^{-14}$ \\
\hline$P(T<=t)$ one-tail & 1.65 \\
\hline$t$ Critical one-tail $\left(t>{ }_{1-\alpha}(203)\right)$ & $1.39 \cdot 10^{-13}$ \\
\hline$P(T<=t)$ two-tail & \multicolumn{2}{|c|}{1.97} \\
\hline$t$ Critical two-tail $\left(|t|>t_{1-\alpha}(203)\right)$ & \multicolumn{2}{|c|}{} \\
\hline
\end{tabular}

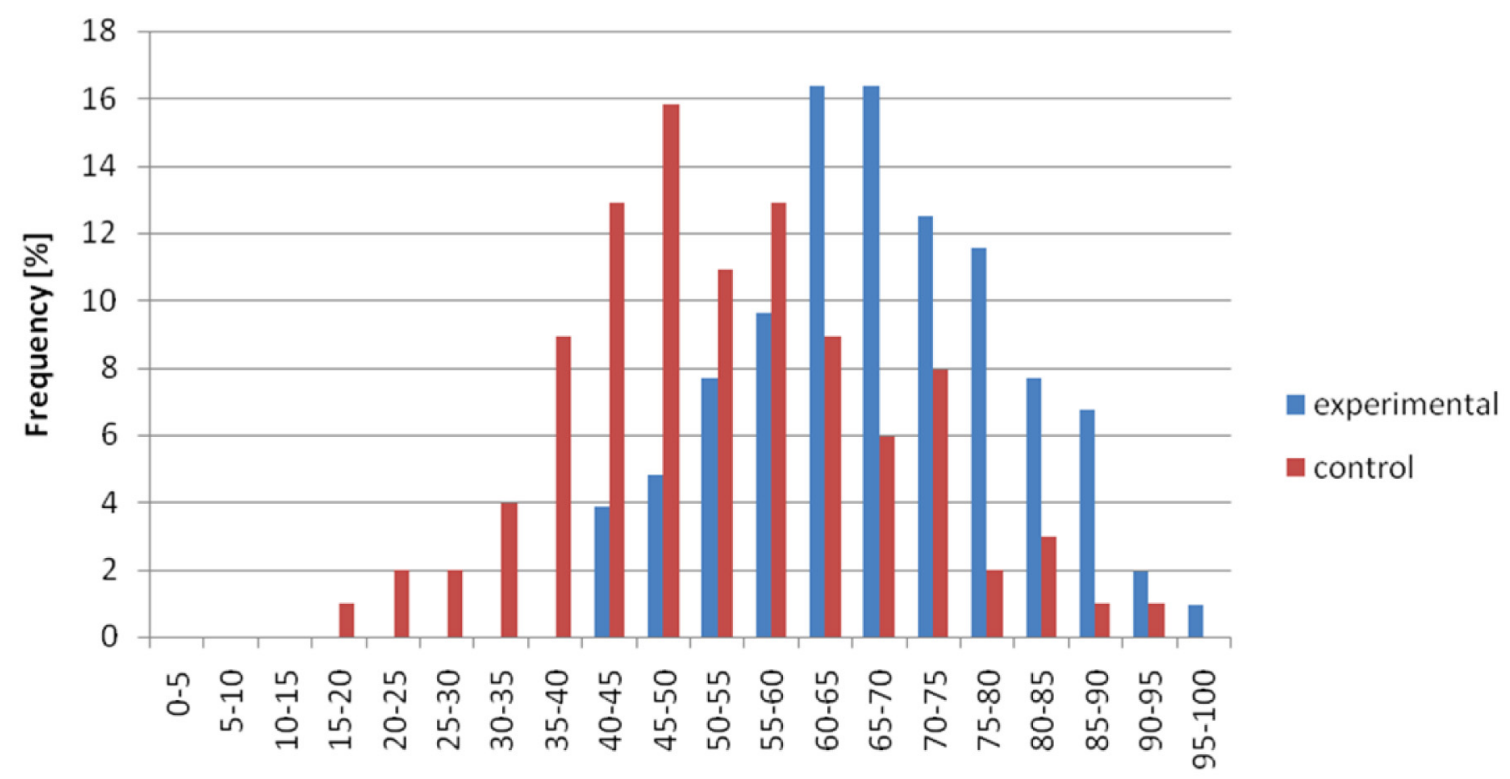

Sucessfullnes [\%]

Figure 1: Test successfulness histogram in the control and experimental group. (control group: $N=101$, Mean $=53.5 \%$, Stand. Dev. $=14.54 \%$, Max $=92 \%$, Min $=20 \%$, experimental group: $N=104$, Mean $=68.4 \%$, Stand. Dev. $12.28 \%$, $\operatorname{Max}=96 \%, \operatorname{Min}=42 \%$ )

Let's have a closer look at the verification of $\mathrm{H}_{1}$ hypothesis (hypotheses $\mathrm{H}_{2}$ and $\mathrm{H}_{3}$ were verified analogically). The score of the posttest in both groups met the condition of normal distribution (normal distribution was verified via KolmogorovSmirnov Test). Results in the charts (Fig. 1) and (Tab. 5) show that there is a difference between knowledge of pupils in experimental and control group shown in the test (in tasks aimed at specific and non-specific transfer). Statistical analysis of characteristics in both groups confirmed that it is possible to test the null hypothesis $\mathrm{H}_{0}$ : The percentage of successfulness in experimental and control group is equal: $\mathrm{H}_{0}$ : 
$\mu_{1}=\mu_{2}$ (vs. $\mathrm{H}_{1}: \mu_{1} \neq \mu_{2}$ ). Statistical verification of the hypothesis was carried out on a significance level 0.05 using two-sample T-test and F-test.

At first the F-test was used to assess the equality of variances. The null hypothesis was stated: $\mathrm{H}_{01}: \sigma_{1}^{2}=\sigma_{2}^{2}$ versus $\mathrm{H}_{11}: \sigma_{1}^{2} \neq \sigma_{2}^{2}$. The null hypothesis is rejected if the value $F=\frac{S_{1}^{2}}{S_{2}^{2}}$ is too high or too low $\left(S_{1}^{2}, S_{2}^{2}\right.$ are variances for experimental and control group). Critical value of Fisher-Snedecor distribution with degrees of freedom $n_{1}-1$ and $n_{2}-1$ is illustrated in Tab. 5. As $F<F_{\text {critical }}$; hypothesis $\mathrm{H}_{01}$ : $\sigma_{1}^{2}=\sigma_{2}^{2}$ for equal variances cannot be rejected.

Following, the hypothesis of equally acquired score in the control and experimental groups $\left(\mathrm{H}_{0}: \mu_{1}=\mu_{2}\right)$ was tested. Independent two-sample Student T-test for unequally large populations and equal variances was used. As $t>t_{\text {critical (two-tail) }}$ the hypothesis $\mathrm{H}_{0}$ was rejected and hypothesis $\mathbf{H}_{1}: \mu_{1}>\mu_{2}$ was confirmed. While solving the tasks of didactic test the pupils in experimental group achieve better results, from the point of view of statistical significance, in the area of specific and non-specific transfer than pupils taught traditionally.

\section{Summary of Research Results}

Analogically to hypothesis $\mathrm{H}_{1}$, also further hypotheses were statistically evaluated. Validity of operational hypotheses is summarised in following table (Tab. 6).

Table 6: Summary of individual hypotheses verification

\begin{tabular}{|c|c|c|c|}
\hline Hypothesis & $\begin{array}{c}\text { Method of data } \\
\text { acquisition }\end{array}$ & Hypothesis validity & Researched value \\
\hline $\mathrm{H}_{1}$ & DT - posttest & valid & $\begin{array}{c}\text { Specific and } \\
\text { non-specific } \\
\text { transfer }\end{array}$ \\
\hline $\mathrm{H}_{2}$ & DT - posttest & valid & Remembering \\
\hline $\mathrm{H}_{3}$ & DT - posttest & valid & Understanding \\
\hline
\end{tabular}

From statistical analyses and results of partial hypotheses testing it is possible to say that on the selected significance level 0.05 and under given conditions the initial hypothesis is confirmed and true. Research into the use of presented multimedia DVD from nuclear physics shows that:

- Pupils taught by the multimedia DVD from nuclear physics achieved higher performance in the didactic test in the area of specific and non-specific transfer, understanding and remembering at the end of the experimental education than the pupils taught traditionally.

- Pupils taught by the multimedia DVD from nuclear physics learned more actively during lessons than the pupils taught traditionally.

Via a detailed analysis of the results obtained during the pedagogical experiment, evaluation of didactic tests and questionnaires and after the consultations with teachers and pupils it can be concluded that:

1. The use of experiments and problem tasks from nuclear physics in the teaching process contributes to achieving of higher performance of pupils in experimental groups when compared to pupils from control groups. This fact was shown 
in partial evaluation of the didactic test (individually evaluated tasks aimed at remembering, understanding, specific and non-specific transfer), as well as in overall evaluation of the didactic test. This trend was shown also in the case of good as well as weaker pupils (following a mark from Physics at the end of the school year).

2. The pupils achieved the worst results during the traditional teaching (in control groups) in the most difficult tasks (aimed at specific and non-specific transfer) what confirmed the research of I. Halloun and D. Hestenes (and others) that traditional form of teaching leads to declarative knowledge only. This kind of knowledge does not represent conceptual understanding of the topic being dealt with. This trend was shown also in the case of good as well as weaker pupils. The use of interactive methods and problem tasks (e.g. P\&E method) can lead to significantly better results.

3. From the interviews with the teachers and pupils resulted that the use of pupils and demonstration experiments from nuclear physics in the teaching process contributes to the increase in he principle of the curriculum demonstration, includes pupils into all stages of the teaching and learning process and thus encourages active working.

4. Pupils liked nuclear physics experiments very much; after the topic of nuclear physics they evaluated the subject as a more interesting, more understandable, more popular and attractive subject.

\section{Conclusion}

Nuclear physics belongs to the most difficult areas of Physics dealt with at lower secondary schools. The use of experiments from nuclear physics, when dealing with this topic, should be obvious at all lower secondary schools. The use of such experiments enables the pupils an easier understanding of this difficult topic.

\section{BIBLIOGRAPHY}

ARONS, A. B. Achieving Scientific Literacy. Daedalus, Spring, 1983 (český preklad: Cesta k přírodovědní gramotnosti I, II In Čs. čas. fyz. A35, 1985, s. 58-68), s. (151-158).

ARONS, A. B. Teaching Introductory Physics. A guide to Teaching for Learning and Understanding. New York: John Wiley and Sons, 1997.

BROWN, D., COX, A. J. Innovative Uses of Video Analysis. The Physics Teacher, vol. 47, no. 3, p. 145-150, 2009.

BUSSEI, P., MERLINO, S. European workshop on Multimedia in Physics Teaching and Learning. Europhysics News, 34(3), 2003, p. 116-117.

CAmpBell, J., BOURne, J., MOSTERMAn, P., BRODERSEN, A. The effectiveness of learning simulations for electronic laboratories. Journal of Engineering Education, 91(1), 2002, 81-87. 
CROUCH, C. H., MAZUR, E. Peer Instruction: Ten Years of Experience and Results. Am. J. Phys. 69(9), 2001.

DEMKANIN, P., PIŠÚT, J., VELMOVSKÁ, K. Vybrané faktory prispievajúce k rozvoju kompetencii žiakov pri vyučovani fyziky. FMFI UK Bratislava, 2011.

DVOŘÁK, L., ET AL. Lze učit fyziku zajímavěji a lépe? Příručka pro učitele. Praha: Matfyzpress, Univerzita Karlova, 2008.

DYKSTRA, D. I., BOYLE, C. F., MONARCH, I. A. Studying conceptual Change in learning physics. Science Education, 1992 (6), p. 615-652.

FINKELSTEIN, N. D., ADAMS, W. K., KELlER, C. J., KOHL, P. B., PERKINS, K. K., . . , LeMASTER, R. When learning about the real world is better done virtually: A study of substituting computer simulations for laboratory equipment. Physical Review Special Topics - Physics Education Research, 1(1), 2005, 1-7.

HAKE, R. R. Interactive-engagement versus traditional methods: A six-thousandstudent survey of mechanics test data for introductory physics courses. American Journal of Physics 66(1998), p. 64-74.

HALLOUN, I., HESTENES, D. The initial knowledge state of college physics students. Am. J. Phys. 53 (1985), 1043-1055.

HANČ, J., TÓTH, J. Pojmy súvisiace s pojmom sila - Force concept inventory (FCI). 2006, Dostupné 18. 12. 2012.

$\langle$ http://physedu.science.upjs.sk/metody/testy.html $\rangle$

HANČ, J., DEGRO, J., JEŠKOVÁ, Z., KIREŠ, M., ONDEROVÁ, L., ČUKANOVÁ, E., KONKOLOVÁ, M. Rozumejú alebo memorujú vaši žiaci fyziku, ktorú učíte? Štandardizované konceptuálne a postojové testy ako nástroje hodnotenia výučby. DIDFYZ 2006, Nitra 2007.

HESTENES, D., WELLS, M., SWACKHAMER, G. Force Concept Invertory. Phys. Teach. 30 (1992), 141-158.

HOCKICKO, P. Nontraditional Approach to Studying Science and Technology. Communications, Vol. 12, No. 3, 2010, p. 66-71.

HOCKICKO, P. Forming of Physical Knowledge in Engineering Education with the Aim to Make Physics More Attractive. Proceedings SEFI - PTEE 2011 (Physics Teaching in Engineering Education), Mannheim, Germany (2011).

HOLEC, S., RAGANOVÁ, J., HRUŠKA, M., SPODNIAKOVÁ PFEFFEROVÁ, M., BULLA, M., MURÍN, M. Integrovaná prírodoveda v experimentoch. Banská Bystrica : Fakulta prírodných vied UMB, 2004. 216 s.

KRIŠŤÁK, L. Experimenty z jadrovej fyziky na gymnáziách. Dizertačná práca. FPV UMB BB. 2007.

KRIŠŤÁK, L. Komparácia učebných textov z jadrovej fyziky na Slovensku a v niektorých krajinách EU. Mladí vedci 2008, UKF Nitra.

KRIŠŤÁK, L., NĚMEC, M. Inovácia Fyzikálneho vzdelávania na TU vo Zvolene, vedecká monografia, TU Zvolen 2011.

KRUPOVÁ, I. The Development of Natural Science Literacy in Pupils in the First Stage of Basic School Using the Method of Managed Discovery. Pedagogika, Vol. LIX, No. 3, 2009, p. 259-268. 
MARTIN-BLAS, T., SEIDEL, L., SERRANO-FERNANDEZ, A. Enhancing Force Concept Inventory diagnostics to identify dominant misconceptions in first-year engineering physics. European Journal of Engineering Education, Vol. 35, No. 6, 2010, 597-606.

MAZUR, E. Peer instruction. A user's manual. Prentice Hall, New York, 1997.

McDERMOTT, L. C. Oersted medal lecture 2001: Physics Education Research The Key to Student Learning. In Am. J. Phys., 69(2001), p. 1127-1137.

NACHTIGALL, D. K. What is wrong with physics teachers' education? Eur. J. Phys. 11(1990) 1-14.

RAGANOVÁ, J., HOLEC, S., HRUŠKA, M., KRIŠŤÁK, L., MURÍN, M., SPODNIAKOVÁ PFEFFEROVÁ, M. Investigations of human-environment interactions. 2007. Dostupné z:

〈http://www.e-prolab.com/en/human-env/human-env.html〉 (18. 12. 2012)

REDISH, E. F. Teaching Physics. John Wiley and Sons, New York, 2003.

REDISH, E. F., STEINBERG, R. N. Teaching physics: Figuring Out What Works. Physics Today, Vol. 52 (1999), p. 24-30.

SHELly, G. B., CASHMAN, T. J., GUNTER, R. E., GUNTER, G. A. Teachers Discovering Computers: Integrating Technology in the Classroom. Thomson Learning, Cambridge, MA, 2001.

SOKOLOFF, D. R., THORTON, R. K. Using interactive lecture demonstrations to create an active learning environment. Phys. Teach. 35(6), 1997.

STURM, B. Science in School. Issue 13, Autumn, 2009, 29.

ZACHARIA, Z., ANDERSON, O. R. The effect of an interactive computer-based simulation prior to performing a laboratory inquiry-based experiment on students' conceptual understanding of physics. American Journal of Physics (2003), Vol. 71, p. 618.

ZELENICKÝ, L. Úloha fyzikálneho experimentu vo vyučovaní. In MEDACTA'91 čast' 3. Nitra : Pedagogická fakulta, 1991.

ŽÁC̆OK, L. Research examination of the options to increase the education effectiveness in the technical subjects at the 7 th grade of elementary school using hypertext educational material. Informatics in Education, 9(2), 2010, 283-299.

\section{ACKNOWLEDGEMENT}

This paper was elaborated with the support of the projects KEGA no. 005UMB4/2011 and KEGA no. 011UMB-4/2012. 


\section{APPENDIX}

\section{TEST FROM NUClEAR Physics FOR THE $9^{\mathrm{TH}}$ GRADE OF PRIMARY SCHOOL}

1. Consider 6 isotopes: ${ }_{26}^{54} \mathrm{~A},{ }_{29}^{63} B,{ }_{27}^{56} C,{ }_{25}^{56} D,{ }_{28}^{64} E,{ }_{26}^{55} F$

a) which two isotopes are isotopes of the same element?

b) which two have the same number of particles in nucleus?

c) which two have the same number of neutrons in nucleus?

d) which one has the highest proton number?

e) which one has the highest nucleon (mass) number?

2. What are natural radionuclides?

3. Radionuclide of polonium ${ }_{84}^{218} \mathrm{Po}$ emits alpha particle. Write this radioactive decay.
a) ${ }_{84}^{218} \mathrm{Po} \rightarrow{ }_{82}^{214} \mathrm{~Pb}+{ }_{2}^{4} \alpha$,
b) ${ }_{84}^{218} \mathrm{Po} \rightarrow{ }_{82}^{216} \mathrm{~Pb}+{ }_{2}^{2} \alpha$,
c) ${ }_{84}^{218} \mathrm{Po} \rightarrow{ }_{83}^{214} \mathrm{Bi}+{ }_{1}^{4} \alpha$
d) ${ }_{84}^{218} \mathrm{Po} \rightarrow{ }_{80}^{216} \mathrm{Hg}+{ }_{4}^{2} \alpha$

Bismuth nucleus ${ }_{83}^{210} \mathrm{Bi}$ emits beta particle. Write this radioactive decay
a) ${ }_{83}^{210} \mathrm{Bi} \rightarrow{ }_{83}^{210} \mathrm{Bi}+\mathrm{e}^{-}$,
b) ${ }_{83}^{210} \mathrm{Bi} \rightarrow{ }_{84}^{210} \mathrm{Po}+\mathrm{e}^{-}$,
c) ${ }_{83}^{210} \mathrm{Bi} \rightarrow{ }_{82}^{210} \mathrm{~Pb}+\mathrm{e}^{-}$,
d) ${ }_{83}^{210} \mathrm{Bi} \rightarrow{ }_{84}^{211} \mathrm{Po}+\mathrm{e}^{-}$

4. Radionuclide of nitrogen ${ }_{7}^{14} \mathrm{~N}$ has half life 24 minutes. Determine the time of radioactive decay during which the original sample of nitrogen radionuclide of $2 \mathrm{~g}$ reduces its weight to $250 \mathrm{mg}$.

5. What are artificial radionuclides and where are they used?

6. Explain the meaning of the word nuclide. What nuclides does hydrogen have?

7. What forces are there between the protons of an element nucleus?

8. In which elements does spontaneous nucleus decay occur? How is this phenomenon called?

9. What is in an active zone of a nuclear reactor?

10. Describe nuclear synthesis.

11. What are the conditions of radioactive waste storage?

12. What are three basic ways of protection against radiation? 
13. Classify materials with the same thickness according to the extent of gamma radiation transition. Start with the one that transmits gamma radiation the most:

air - lead - aluminium - paper
a) air - paper - aluminium - lead,
b) paper - air - aluminium - lead,
c) air - aluminium - paper - lead,
d) air - paper - lead - aluminium

14. Describe uranium ${ }^{235} \mathrm{U}$ fission.

15. What do you know about first artificial radionuclide?

16. Enrico Fermi.

17. Explain the term isotope.

L’uboš Krišták - E-mail: kristak@tuzvo.sk

Technical University in Zvolen, Faculty of Wood Sciences and Technology

Department of Physics, Electrical Engineering and Applied Mechanics

T. G. Masaryka 24, 96053 Zvolen, Slovak Republic

Ján Stebila - E-mail: jan.stebila@umb.sk

Matej Bel University, Faculty of Natural Sciences

Department of Techniques and Technologies

Tajovského 40, Banská Bystrica, Slovak Republic

Zuzana Danihelová - E-mail: zuzana.danihelova@tuzvo.sk

Technical University in Zvolen

Institute of Foreign Languages

T. G. Masaryka 24, 96053 Zvolen, Slovak Republic 